\title{
The fate of suboptimal anastomosis after colon resection: An experimental study
}

\author{
Mehmet Kamil Yıldız, M.D., ${ }^{1}$ İsmail Okan, M.D., ${ }^{2}$ Hasan Nazik, M.D., ${ }^{3}$ Gurhan Bas, M.D., ${ }^{4}$ \\ Orhan Alimoglu, M.D., ${ }^{5}$ Mehmet İlktac, M.D., ${ }^{3}$ Emin Daldal, M.D., ${ }^{6}$ \\ Mustafa Sahin, M.D., ${ }^{2}$ Nuray Kuvat, M.D., ${ }^{3}$ Betugul Ongen, M.D. ${ }^{3}$
}

\begin{abstract}
1Department of General Surgery, Haydarpaşa Numune Training and Research Hospital, İstanbul;
${ }^{2}$ Department of General Surgery, Gaziosmanpaşa University Faculty of Medicine, Tokat;

${ }^{3}$ Department of Microbiology and Clinical Microbiology, İstanbul University İstanbul Faculty of Medicine, İstanbul;

${ }^{4}$ Department of Surgery, Ümraniye Training and Research Hospital, İstanbul;

${ }^{5}$ Department of Surgery, Medeniyet University Göztepe Training and Research Hospital, İstanbul;

${ }^{6}$ Department of General Surgery, Vakıf Gureba Training and Research Hospital, İstanbul
\end{abstract}

\begin{abstract}
BACKGROUND: The fate of suboptimal anastomosis is unknown and early detection of anastomotic leakage after colon resection is crucial for the proper management of patients.

METHODS: Twenty-six rats were assigned to "Control", "Leakage" and "Suboptimal anastomosis" groups where they underwent either sham laparotomy, cecal ligation, and puncture or anastomosis with four sutures following colon resection, respectively. At the fifth hour and on the third and ninth days; peripheral blood and peritoneal washing samples through relaparotomy were obtained. The abdomen was inspected macroscopically for anastomotic healing. Polymerase chain reaction (PCR) with I6s rRNA and E.coli-specific primers were run on all samples along with aerobic and anaerobic cultures.
\end{abstract}

RESULTS: The sensitivity and specificity of PCR on different bodily fluids with 16 s rRNA and E.coli-specific primers were $100 \%$ and $78 \%$, respectively. All samples of peritoneal washing fluids on the third and ninth days showed presence of bacteria in both PCR and culture. The inspection of the abdomen revealed signs of anastomotic leakage in eight rats $(80 \%)$, whereas mortality related with anastomosis was detected in two (20\%).

CONCLUSION: Anastomotic leakage with suboptimal anastomosis after colon resection is high and the early detection is possible by running PCR on peritoneal samples as early as 72 hours.

Key words: Anastomotic leakage; colorectal anastomosis; early detection; polymerase chain reaction; suboptimal anastomosis.

\section{INTRODUCTION}

Anastomotic leakage is one of the most feared complications of colorectal surgery. Although reported rates of anastomotic leakage vary between $1 \%$ and $23 \%, 3 \%$ to $6 \%$ rate is considered acceptable for modern surgery. ${ }^{[1]}$ Besides many negative

Address for correspondence: Mehmet Kamil Yıldız, M.D.

Bulgurlu Mahallesi, Söğütlüçayır Cadddesi, Aydınevler Sitesi, No: 21, B Blok, D: 16, Üsküdar, İstanbul, Turkey

Tel: +90 216 - 553725 I E-mail: mehmetkamilyildiz@yahoo.com

Qucik Response Code Ulus Travma Acil Cerrahi Derg

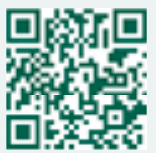

20I4;20(6):40I-409

doi: $10.5505 /$ tjtes.2014.31899

Copyright 2014

TJTES impacts on patient's morbidity, mortality and life quality, it is also associated with higher tumor recurrence rate and poor survival. ${ }^{[2,3]}$

Wide variations in reported incidences of colorectal anastomotic leakage are partly due to lack of consensus on the definition. There have been several reports using highly variable definitions of anastomotic leakage in colorectal surgery. ${ }^{[4]}$ A recent consensus definition of anastomotic leakage as " $a$ communication between intra-and extraluminal compartments owing to a defect of the integrity of the intestinal wall at the anastomosis between colon and rectum or the colon and anus" has been proposed by International Study Group of Rectal Cancer. ${ }^{[4]}$ Although more general, UK Surgical Infection Study Group has also defined anastomotic leakage as the "leak of luminal contents from a surgical join between two hollow viscera". ${ }^{[5]}$ While many studies used clinical signs 
of peritonitis such as fever, tachycardia, leukocytosis, and etc.; some used radiological findings detected by computed tomography (CT) or other modalities. Lack of consensus in detection methods could partly explain the reason of great variations in the incidence and outcome of the leakage.

Although clinical anastomotic leakage has received great interest in surgery, the fate of suboptimal anastomosis is largely unknown. Since the presenting clinical symptoms are often vague and confused with benign postoperative complications, the true rate of anastomotic leakage is difficult to estimate. It is important to distinguish leakage from such benign conditions to act as early as possible in order to avoid severe consequences. The luminal contents leaked into peritoneum are principally cleared by local defense mechanisms. However, bacteria in the peritoneum can easily find access to the bloodstream in a very short time. ${ }^{[6]}$ The early detection of microorganism in the peritoneum and blood could alter the management of the patient. Since conventional methods of bacterial detection such as culture is sometimes insufficient, molecular techniques like polymerase chain reaction (PCR) could be of assistance. PCR has been shown to detect small amount of bacteria in different bodily fluids with great success. ${ }^{[7]}$ However, the role of PCR in the early detection of anastomosis is not clearly depicted.

This experimental study was designed to understand the fate of suboptimal anastomosis and explore the possibility of early diagnosis of leakage in colon anastomosis by means of detecting bacterial DNA in different bodily fluids by polymerase chain reaction. It was also aimed to evaluate the efficacy of $\mathrm{PCR}$ in anastomotic leaks.

\section{MATERIALS AND METHODS}

Animals

The local Animal Ethics Committee of Istanbul University, Faculty of Medicine approved the experiment (Protocol number: 28/2005, Protocol Date: 20.09.2005). Twenty-six male Wistar rats weighing 200-250 grams were used. National Research Council guidelines were followed for the use and care of the animals. Briefly, the animals were put two per cage, fed on standard chow, and let free access to water. They were observed for two weeks before the experiment started. They were allowed to eat and drink before and after the operation. The animals were followed for two months after the operation.

\section{Experimental Design}

The animals were randomly assigned to three groups: Group I was the "control group" consisted of eight animals which underwent sham laparotomy. Five hours after the operation, peripheral blood sample was obtained to evaluate any bacterial contamination by PCR and culture. Group II was the "leakage group" and consisted of eight animals. After laparotomy, the cecal ligation and puncture were performed and the abdomen was closed. Five hours later, peripheral blood was withdrawn and both PCR and culture were run on blood samples to detect bacterial presence. The rats were then sacrificed. Group III was the "suboptimal anastomosis group" and consisted of ten animals. After laparotomy, resection of the left colon and anastomosis were performed. Five hours, three and nine days after the operation, peripheral blood samples were taken to run PCR and culture. On the third and ninth days, the rats underwent relaparatomy. Peritoneal fluid collections were obtained for both PCR and culture. The abdomen was inspected and anastomosis was evaluated macroscopically for healing. Experimental design was summarized in Figure I.

\section{Procedures and the Operation}

All interventional procedures and operations were performed under strict sterility and dissociative anesthesia. Intramuscular $90 \mathrm{mg} / \mathrm{kg}$ ketamine $\mathrm{HCl}$ (Ketalar, Parke-Davis, Eczacibasi, Turkey) was used for anesthesia. Peripheral blood to study the bacteremia with PCR and culture was withdrawn from the femoral region. In order to prevent contamination from skin bacteria, the femoral region was cleaned with polyvinyl pirolidon iodine (Batticon, Adeka, Turkey). Groin region was covered with sterile drapes and an incision of $2 \mathrm{~cm}$ was made. Under sterile conditions, femoral artery was found and I to 2 $\mathrm{ml}$ of blood was withdrawn into 2 Na2EDTA containing sterile tubes. One blood sample was used for DNA isolation and placed on ice immediately and transferred to $-20^{\circ} \mathrm{C}$ freezers until analysis. The blood in the second tube was inoculated into cultural medium. For each time point, opposite site of the femoral region from the previous attempt was used to minimize the contamination risk. The femoral region was sutured after the procedure under sterile condition.

Laparotomies were performed via 3-cm midline incisions after cleaning the surgical area with povidone iodine and covering with sterile drapes. The area was covered to prevent spillage. A segment of left colon was isolated and resected without compromising the vasculature network. Anastomosis of the resected colon was performed with four sutures using 4/0 vicryl suture. The use of less than five sutures in anastomosis has been defined as a model for suboptimal anastomosis. ${ }^{[8]}$ Then, the abdominal wall and skin were closed with $3 / 0$ silk sutures.

Seventy-two hours later, the animals were prepared for peripheral blood withdrawal under anesthesia with strict adherence to asepsis, as described. After the closure of the femoral incision, the abdomen was incised and subcutaneous tissue was inspected for abscesses. In case of abscess, discharge sample was obtained for both PCR and culture. Abdominal wall was opened through previous sutures. Without touching the abdominal organs, abdominal cavity was washed with 2 $\mathrm{ml}$ of sterile saline and the fluid was collected with a syringe. Afterwards, inspection of the abdomen and anastomosis was 


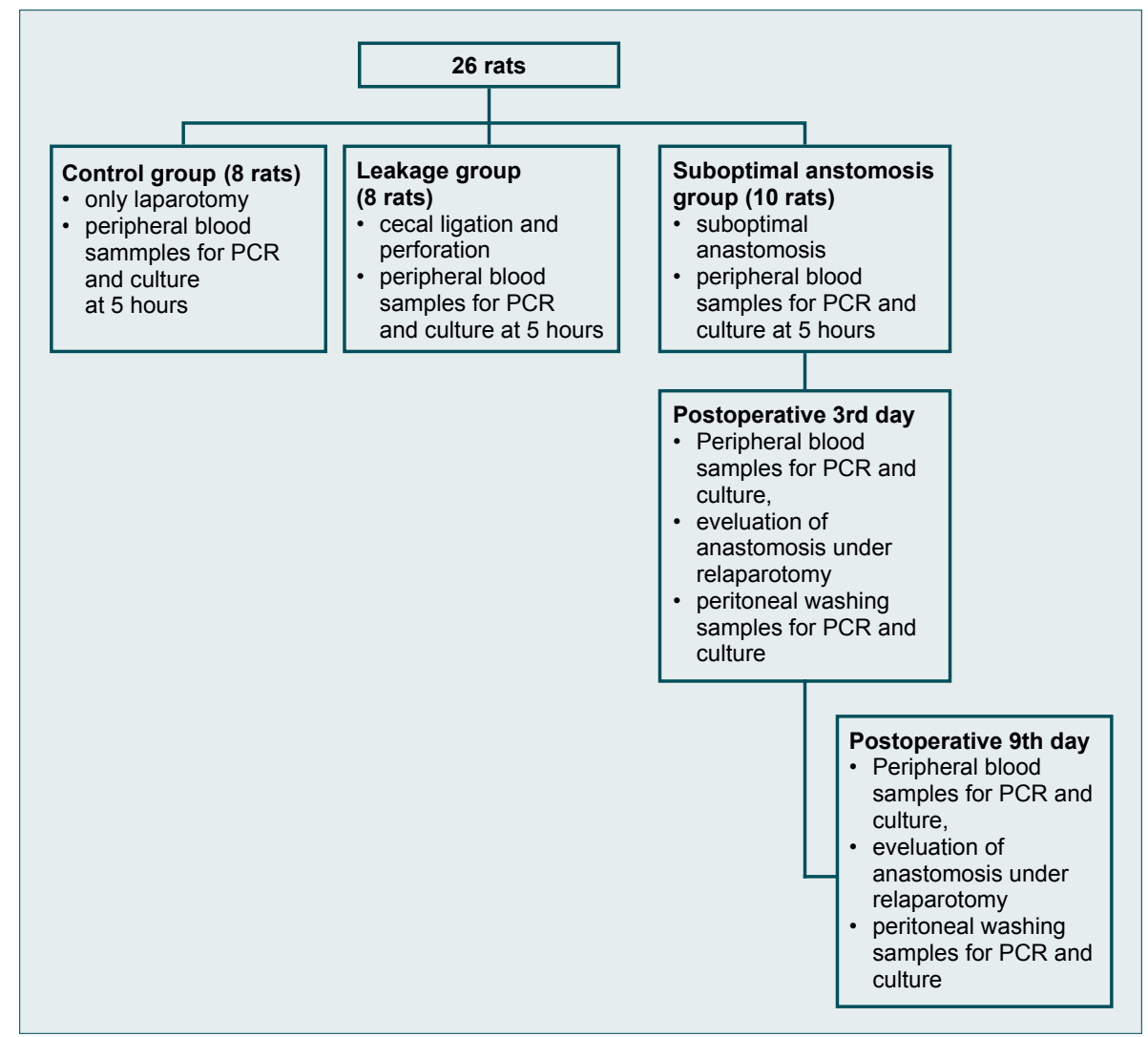

Figure 1. An overview of the experimental design.

performed. Any collections in the abdominal cavity were noted and anastomosis was evaluated. The leak was considered in the case of gross contamination with luminal content, the presence of healing defect in anastomosis, the presence of small abscess around anastomosis, and the omental attachment covering the healing defect. The abdomen was closed in an orderly fashion. After nine days, the same procedures with peripheral blood withdrawal and anastomosis evaluation were repeated. The animals were followed for a two-monthperiod for observation. Any animal lost during study period underwent autopsy and the abdominal cavity and anastomosis were evaluated.

\section{The Detection of Bacterial DNA in the Blood and} Peritoneal Fluid

\section{DNA Isolation}

All samples collected from each animal were stored at $-20^{\circ} \mathrm{C}$. For the extraction of DNA, 200-400 uL blood, whole blood or peritoneal wash fluid were used. DNA was extracted from whole blood or peritoneal fluid using the DNA extraction kit (Roche Diagnostics GmbH, Mannheim, Germany,) according to the manufacturer's protocol. DNA samples were stored at $-20^{\circ} \mathrm{C}$.

\section{Polymerase Chain Reaction}

Two primer pairs were used for the detection of bacteria.
First set of primers ( $540 \mathrm{bp}$ ) were used to amplify prokaryotic I6S rRNA for the detection of any bacterial contamination regardless of origin: 355F (5'-CCTACGGGAGGCAGCAG-3'), and 9IOR (5'-CCCGTCAATTCCTTTGAGTT -3'). [9] The second set of primers (486 bp) were used to amplify $\beta$ - glucuronidase of Escherichia coli to detect $E$. coli specifically: PI (5'-ATCACCGTGGTGACGCATGTCGC-3') and P2 (5'-CACCACGATGCCATGTTCATCTGC-3'). ${ }^{[10]} 40 \mathrm{ul}$ of reaction mixture was formed from Ix PCR buffer, $3.5 \mathrm{mmol} / \mathrm{L}$ $\mathrm{MgCl}_{2}, 2 \cup$ Taq DNA polymerase, $800 \mu \mathrm{mol} / \mathrm{L}$ dNTP mix, I $\mu \mathrm{mol} / \mathrm{L}$ primer I, and I $\mu \mathrm{mol} / \mathrm{L}$ primer 2 , and $10 \mathrm{ul}$ extracted DNA was used for the 50 ul of total volume of PCR mixture. The amplification reaction consisted of one cycle of $5 \mathrm{~min}$ at $94^{\circ} \mathrm{C}$ and 35 cycles of $45 \mathrm{~s}$ of denaturation at $94^{\circ} \mathrm{C}, 45$ $\mathrm{s}$ of annealing at $55^{\circ} \mathrm{C}$, and $60 \mathrm{~s}$ of extension at $72^{\circ} \mathrm{C}$, with a final extension cycle of $10 \mathrm{~min}$ at $72^{\circ} \mathrm{C}$. At the end of the program, $10 \mathrm{ul}$ of the amplification product was detected by electrophoresis on $1.5 \%$ agarose gel with ethidium bromide staining, and the products were then photographed under UV light (304 nm). The amplified DNA products (I 6s rRNA, 540 bp; and E. coli-specific, 486 bp) were compared with control DNA and molecular weight standards.

\section{Cultures}

One $\mathrm{ml}$ of blood and peritoneal samples collected from rats were inoculated into BACTEC aerobic and anaerobic medium bottles (Becton Dickinson, Sparks, Md.) in order to detect 
bacterial growth. After incubation for seven days at $37^{\circ} \mathrm{C}$, the bottles were punctured under sterile conditions, and $100 \mu \mathrm{l}$ was subcultured onto sheep blood (5\%) agar and MacConcey agar medium. A subculture was incubated in anaerobic conditions at the same time. The subcultures were incubated for 72 hours at $37^{\circ} \mathrm{C}$. If bacterial growth was detected, the bacteria were identified according to standard microbiological methods.

\section{Statistical Analysis}

The sensitivity, specificity, negative and positive predictive value of PCR compared to culture was calculated. Presence of bacterial DNA in either $E$. coli or I6s rRNA, PCR was accepted as positive. Being negative in PCR meant both PCR samples ( $E$. coli and I6s rRNA) didn't detect any bacterial DNA.

\section{RESULTS}

\section{General}

Two mortalities were observed in the suboptimal anastomosis group, while no mortality was detected in the control group. One of the rats died at the forty-eighth hour. Blood samples for both PCR and culture were positive at the fifth hour of anastomosis and E. coli, Klebsiella sp. and Bacteroides fragilis were identified from culture. Exploration of the abdomen revealed complete dehiscence of anastomosis with gross fecal contamination. The PCR and cultures run on blood sample at the forty-eighth hour and peritoneal washing cultures were positive for $E$. coli and $B$. fragilis. The second rat died on the sixteenth day of anastomosis. PCR and cultures from blood and peritoneal samples until postoperative ninth day were all negative for any bacterial presence. However, on ninth day, blood and peritoneal samples showed positivity for PCR. Culture identified E. coli, K. pneumoniae and $B$. fragilis. Nevertheless, inspection of the abdomen on the ninth day didn't show any gross contamination of fecal material and anastomosis healing was normal. On postmortem examination sixteenth day, complete dehiscence of anastomosis with gross contamination of abdomen was noted.

The inspection of anastomosis on postoperative third day revealed that $80 \%$ of anastomosis showed some signs of anas-

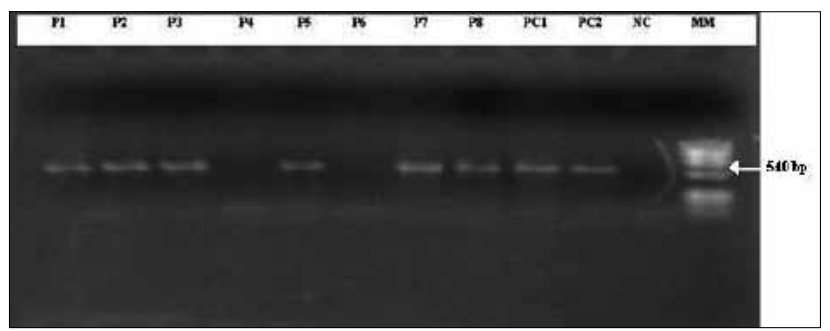

Figure 2. Gel electrophoresis of PCR products run on blood samples obtained at the fifth hour from the rats. (PC: Positive control, NC: Negative control; MM: Molecular marker; P1-P8: blood samples of the rats from leakage group. $16 \mathrm{~s} r$ RNA primers were used). tomotic leakage either at one time point or both (Fig. 3). Leaked anastomosis were covered by omentum and associated with microabscesses showing some signs of inflammation. On ninth day, more anastomosis appeared healed macroscopically $(66 \%)$.

\section{The Sensitivity and Specificity of PCR}

Sixty eight samples (blood, peritoneal washings, wound and abcesses) from 26 rats were cultured. Two PCRs, one with E. coli primers and other with 16s rRNA primers, were run on each sample ending up with a total number of I36 PCRs. The sensitivity and specificity of PCR with both E. coli primers and 16s rRNA primers on samples from different body fluids were found $100 \%$ and $78 \%$, respectively (Table I). The accuracy of PCR samples from blood, peritoneal washings, and wound abscesses changed from $84 \%$ to $100 \%$ depending on the primers and the sample type. The sensitivity of PCR was $100 \%$, regardless of the primers and sample type, while the specificity changed between 57 and 100\% depending on primers and samples. The negative predictive value of PCR was found $100 \%$. However, the positive predictive value was between 65 to $100 \%$. The details of sensitivity, specificity and accuracy with the use of different primers on different bodily fluids were shown in Table 2. The accuracy of PCR using $E$. coli primers on any sample $(97 \%)$ was greater than the one using 16 s rRNA primers (88\%).

\section{Early Detection of Bacterial DNA in the Blood of Rats With Gross Abdominal Leak}

Animals in the leakage group served as control group for the gross bacterial contamination. After five hours of cecal ligation and puncture, the animals were sick-appearing with tachypnea and lethargy. The culture performed on blood

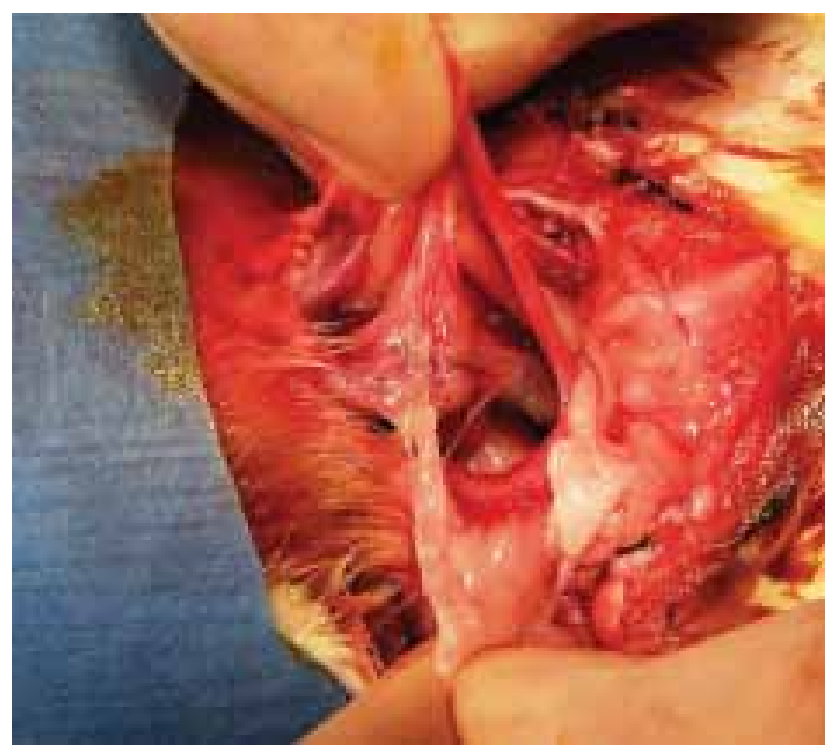

Figure 3. Macroscopic examination of anastomosis. Please note suture and adhesions, edema and inflammation around the anastomosis. 
Table I. Comparison of PCR with E. coli primers and I6s rRNA primers run on different body fluids with corresponding cultures

\begin{tabular}{|c|c|c|c|c|}
\hline & & \multicolumn{2}{|c|}{ Culture } & \\
\hline & & Positive & Negative & \\
\hline \multirow[t]{10}{*}{ PCR } & Positive & 35 & 7 & $83 \%$ \\
\hline & & (TP) & (FP) & PPV \\
\hline & & & & $\mathrm{TP} /(\mathrm{TP}+\mathrm{FP})$ \\
\hline & Negative & 0 & 26 & $100 \%$ \\
\hline & & $(\mathrm{FN})$ & $(\mathrm{TN})$ & NPV \\
\hline & & & & $\mathrm{TN} /(\mathrm{TN}+\mathrm{FN})$ \\
\hline & & 35 & 33 & 68 \\
\hline & & $100 \%$ & $78 \%$ & \\
\hline & & Sensitivity & Specificity & \\
\hline & & $\mathrm{TP} /(\mathrm{TP}+\mathrm{FN})$ & $\mathrm{TN} /(\mathrm{FP}+\mathrm{TN})$ & \\
\hline
\end{tabular}

TP: True positive; FP: False positive; PPV: Positive predictive value; FN: False negative; TN: True negative; NPV: Negative predictive value.

samples at postoperative fifth hour from $75 \%$ of rats revealed bacterial growth $(n=6 / 8)$. PCR using with $E$. coli primers revealed no positivity. However, same PCR reaction with $16 \mathrm{~s}$ rRNA primers revealed a complete overlap with culture positivity (Fig. 2). The isolated bacteria from culture were monobacterial in five rats ( $B$. fragilis in four rats, Enterococcus $s p$. in one rat), and multibacterial in one. $B$. fragilis was the most frequently isolated bacteria in the leakage group (83\%). In this group of animals, the accuracy, sensitivity and specificity of PCR were $100 \%$. In the control group with only laparotomy, both PCR with E. coli and I6s rRNA primers and culture were negative for bacterial contamination or growth.

\section{The Detection of Bacteria in the Blood of Rats With Suboptimal Anastomosis}

Five hours after anastomosis, PCR on the blood withdrawn from femoral vein showed two positive results. One had not been confirmed with culture. However, the other one was confirmed with culture since E. coli, B. fragilis, and K. pneumoniae were identified. The rat had gross anastomosis leak on second day of exploration and died. The positivity of bacterial detection at the fifth hour was $20 \%$.

On the third day of anastomosis, three rats showed positivity of bacterial DNA in the PCR. However, the cultures of two rats didn't confirm positivity and correlate with gross anastomosis leak ending with excitus. The only positive result correlating with the culture was the blood sample obtained earlier from the heart of the rat which died at the forty-eighth hour due to anastomotic leak. Therefore, the positivity of bacterial DNA at 72 hours in blood was $30 \%$.

On postoperative ninth day, PCR with E. coli primers was positive on $33 \%$ of rats, whereas PCR with 16 s rRNA primers showed $88 \%$ positivity. Culture showed $60 \%$ positivity on blood. However, the identified bacteria from two cultures showed methicilline sensitive $S$. aureus, which could possibly result from contamination of skin flora. Therefore, if culture positivity with intestinal flora is taken into account, the positivity decreases to $40 \%$. Table 3 summarizes the results.

Table 2. The sensitivity, specificity, NPV (negative predictive value), and PPV (positive predictive value) of PCR with different primers on different body fluids compared with corresponding cultures

\begin{tabular}{|c|c|c|c|c|c|c|}
\hline & \multicolumn{3}{|c|}{ E. coli primers } & \multicolumn{3}{|c|}{ I6s rRNA primers } \\
\hline & All samples (\%) & Blood (\%) & Peritoneal fluid (\%) & All samples (\%) & Blood (\%) & Peritoneal fluid (\%) \\
\hline Sensitivity & 100 & 100 & 100 & 100 & 100 & 100 \\
\hline Specificity & 93 & 100 & 57 & 75 & 78 & 0 \\
\hline PPV & 87 & 100 & 80 & 81 & 65 & 95 \\
\hline NPV & 100 & 100 & 100 & 100 & 100 & NC \\
\hline
\end{tabular}


Table 3. PCR and culture results from blood samples of suboptimal anastomosis group

\begin{tabular}{|c|c|c|c|c|c|c|}
\hline Rat & 5th $h$ & 3rd d & 9th d & $\begin{array}{c}\text { Culture } \\
\text { 3rd d / 9th d }\end{array}$ & $\begin{array}{c}\text { Anastomotic } \\
\text { leak }\end{array}$ & Mortality \\
\hline I & $\mathrm{N}$ & $\mathrm{N}$ & PI6sRNA & Sterile / Sterile & Yes & No \\
\hline 2 & $\mathrm{~N}$ & $\mathrm{~N}$ & PI6sRNA & Sterile / MSSA & No & No \\
\hline 3 & $\mathrm{~N}$ & PI6sRNA & PI6sRNA & Sterile / MSSA & Yes & No \\
\hline 4 & $\mathrm{~N}$ & $\mathrm{~N}$ & PI6sRNA & Sterile / Sterile & Yes & No \\
\hline 5 & $\mathrm{~N}$ & $\mathrm{~N}$ & PEc+16sRNA & Sterile / E. coli & Yes & No \\
\hline 6 & PI6sRNA & PI6sRNA & PI6sRNA & Sterile / Sterile & Yes & No \\
\hline 7 & $\mathrm{~N}$ & $\mathrm{~N}$ & $P E c+16 s R N A$ & Sterile / E. coli, B. fragilis & Yes & No \\
\hline 8 & PI6sRNA & $\mathrm{N}$ & $\mathrm{N}$ & Sterile / Sterile & Yes & No \\
\hline 9 & PI6sRNA & $P E c+16 s R N A^{*}$ & NA & $\begin{array}{c}\text { K. pneumonia\# E.coli", } \\
\text { B. fragilis*/ NA }\end{array}$ & Yes & Yes \\
\hline 10 & $\mathrm{~N}$ & $\mathrm{~N}$ & $P E c+16 s R N A$ & Sterile / E. coli & No & Yes \\
\hline$\%$ & $30 \%$ & $30 \%$ & $88 \%$ & $40 \%^{*}$ & $80 \%$ & $20 \%$ \\
\hline
\end{tabular}

N: Negative; PEc: Positive PCR with E.coli primers; PI6sRNA: Positive PCR with I6s rRNA primers; PEc+16sRNA: Positive PCR with E.coli and I6 s r RNA primers. *Denotes the blood sample obtained at 48 hours of anastomosis. \#Shows the culture result obtained at 5 hours after anastomosis.

Table 4. PCR and culture results from blood samples of suboptimal anastomosis group

\begin{tabular}{|c|c|c|c|c|c|}
\hline Rat & 3rd day & 9th day & $\begin{array}{c}\text { Culture } \\
\text { 3rd d / 9th d }\end{array}$ & Anastomotic leak & Mortality \\
\hline I & $P E c+16 s R N A$ & PI6sRNA & E. coli / MSSA & Yes & No \\
\hline 2 & PEc+16sRNA & PI6sRNA & E. coli / K. pneumonia & No & No \\
\hline 3 & PEc+16sRNA & PEc+16sRNA & E. coli, Fusobacterium / E. coli & Yes & No \\
\hline 4 & PEc+16sRNA & PI6sRNA & E. coli / K. pneumonia & Yes & No \\
\hline 5 & PEc+16sRNA & PEc+16sRNA & E. coli / E. coli & Yes & No \\
\hline 6 & PI6sRNA & PEc+16sRNA & B. fragilis / E. coli & Yes & No \\
\hline 7 & PEc+16sRNA & PEc+16sRNA & Sterile / Proteus spp. & Yes & No \\
\hline 8 & PEc+16sRNA & PEc+16sRNA & K. pneumonia, MSSA / E. coli, B. fragilis & Yes & No \\
\hline 9 & $P E c+16 s R N A^{*}$ & $N A^{\#}$ & E. coli"/ NA & Yes & Yes \\
\hline \multirow[t]{2}{*}{10} & PEc+16sRNA & PEc+16sRNA & E. coli / E. coli & No & Yes \\
\hline & $100 \%$ & $100 \%$ & $100 \%$ & $80 \%$ & $20 \%$ \\
\hline
\end{tabular}

PEc: Positive PCR with E.coli primers; PI6sRNA: Positive PCR with I6s rRNA primers; PEc+16sRNA: Positive PCR with E.coli and I6 s r RNA primers. *Denotes the sample obtained at 48 hours of anastomosis. "The rat died at 48 hours due to anastomotic leak.

\section{The Detection of Bacteria in the Peritoneal} Washing of Rats with Suboptimal Anastomosis

On postoperative third and ninth days, $100 \%$ PCR positivity for bacterial DNA was detected. However, on the third day, $90 \%$ of the culture was positive. On postoperative ninth day, culture positivitiy was $100 \%$. The bacteria isolated from peritoneal washings were all from intestinal flora. In three cultures, MSSA was isolated additionally to gram negative or anaerobic bacteria, which could more likely come from contamination of the surgical procedures. E. coli was present in $90 \%$ of the culture. The details were shown on Table 4 .

\section{DISCUSSION}

Early diagnosis of anastomotic leakage and subsequent treatment are essential for the prognosis and prevention of devastating consequences. It has been shown that reoperation of the patients with anastomotic leakage before postoperative day five of index surgery significantly reduces the mortality compared to patients operated after day five. ${ }^{\left[{ }^{[1]}\right]}$ However, presenting symptoms and timing of the leak vary greatly. Majority of the reports consider gross indicators of clinical situations like peritonitis. However, many patients present with vague or weak symptoms of neurological and respiratory ori- 
gin, which could easily be confused. ${ }^{[12]}$ In many studies, anastomotic leakage has appeared between postoperative seventh and twelfth days with gross signs of peritonitis and systemic sepsis. Traditional signs and symptoms of an anastomotic leak such as elevated white blood cell level (WBC), fever, and peritonitis usually develop as late as postoperative 5-7 days. The return of bowel function after colorectal resection and anastomosis does not preclude the possibility of a leak. ${ }^{[2]}$ Besides clinical indicators, many biochemical and radiological tests have been studied with the expectation of timely diagnosis. ${ }^{[13,14]}$ A recent study using CRP as an indicator of anastomotic leakage after colorectal resection showed that higher levels might help to detect the leage before becoming clinically apparent. ${ }^{[15]}$ The detection of cytokines through intraperitoneal microdialysis has also been implicated as a tool for detection of anastomotic leakage prior to the emerging of clinical symptoms. ${ }^{[16]}$ However, none of the methods have been proven effective and accepted universally.

The fate of bacteria in peritoneal cavity has been studied substantially during last decades. It has been shown that intraperitoneal elimination starts immediately and continues for approximately six hours. ${ }^{[17]}$ The bacteria gain access to circulating blood through the pores located in the abdominal part of the right diaphragm to the thoracic duct and eventually to peripheral blood circulation. The process is very rapid, since the bacteria could be observed in the thoracic duct as early as 6 to 10 min after intraperitoneal injection and in the blood after 30 to $40 \mathrm{~min} .{ }^{[18]}$ The blockade of absorption from peritoneal cavity by destruction of diaphragmatic pores decreased the positive blood culture and increased the survival time in rats with double colonic perforation. ${ }^{[19]}$ However, the detection of small amount of bacteria in blood by conventional methods like blood culture could be ineffective especially in postoperative period while the patient is under antibiotic regime. Recently, PCR based molecular methods have gained acceptance in many aspects of clinical application. The detection of the amount of bacteria in various bodily fluids, like blood, using PCR with specific primers designed from bacterial DNA could be accomplished, even when the patient is under antibiotic treatment. ${ }^{[7,20]}$

The fate of suboptimal anastomosis in humans is largely unknown. There are few reports on minor anastomotic leaks and their comparisons with major ones. Recently, an experimental model of suboptimal anastomosis has been introduced. The authors claim that an animal model of colorectal anastomotic leakage can be created with five interrupted sutures resulting with $44 \%$ of anastomotic leak. ${ }^{[8]}$ In this study, four interrupted sutures were used to establish anastomosis and $80 \%$ of the anastomotic leak was detected with inspection. The bacteria were detected by both PCR and culture in the peritoneal washings (100\% and $90 \%$, respectively). Even as late as the ninth day after anastomosis, PCR and culture showed $100 \%$ positivity with bacteria. The identification of bacteria from culture was clearly from intestinal origin. Based upon our results, it can be suggested that most anastomosis after suboptimal suturing has leaks continuing even after the clinical healing has occurred. Although anastomotic leak continues microbiologically, the healing process becomes completed except in $20 \%$ of anastomosis, which ended up with mortality. This figure also comprised late anastomotic leaks, since the rats were followed for two months after anastomosis. It can be concluded that in suboptimal anastomosis, although anastomotic leak is present microscopically, the leak ending up with mortality only comprises $20 \%$. Our result and clinical experience show that not all anastomotic leakages end up with devastating complications. A variety of different clinical presentations ranging from asymptomatic cases to severe peritonitis ending up with mortality could be seen. While some leaks are contained and healed without intervention, some requires surgery. The question of how a leak will progress could be influenced by many facors related with the host (immune response, genetic variations like single nucleotide polymorphism in critical genes controlling the inflammation), amount of leakage, origin of the leak like from the small or large intestine, virulence of bacteria, and etc. Therefore, the experimental model of suboptimal anastomosis can be used to titrate and investigate the variables controling the outcome of anastomotic leakages.

The use of PCR in different bodily fluids has been studied with great success. ${ }^{[21-24]}$ The PCR method has been found to be more sensitive than blood cultures for detecting bacterial presence in the blood of critically ill surgical patients. ${ }^{[7]}$ The detection of bacterial DNA in the blood of patients with liver cirrhosis, acute pancreatitis, and major abdominal surgery has also been reported. ${ }^{[25-27]}$ The use of PCR in an experimental model of anastomotic leakage has already been shown in a study where the authors claim that the detection of microbial DNA in blood might be used in patients with dubious findings suggesting anastomotic leakage. ${ }^{[28]}$ In this study, it was shown that the sensitivity of PCR was $100 \%$, while the specificity changed between $57 \%$ and $100 \%$. Hence, the negative predictive value of PCR was perfect as shown earlier. In other words, by negative PCR any infectious source can be ruled out. Low positive predictive level was expected since the detected DNA could come from dead organisms, which had already been phagocytosed and engulfed. The difference between the detection rates of anastomotic leakages (100\% with PCR and culture, $80 \%$ by inspection) could partly be explained by the sensitivity of PCR. Furthermore, a miniscule anastomotic leakage can be missed by the naked eye, while PCR and culture are more sensitive since they detect the bacterial contamination to the peritoneum. The bacterial detection in suboptimal anastomosis either by PCR or culture at both time points from peritoneal washings was significantly higher than the blood. Using peritoneal washing solutions, PCR can detect the presence of bacteria significantly earlier and more precisely than blood. In the presence of anastomotic leakage, the management mainly depends on the patient's clinical situation and response. However, there 
are some circumstances where symptoms are dubious to suggest anastomotic leakage. Although the decision will still be clinically oriented, earlier diagnosis of anastomotic leakage strongly helps clinicians to direct the treatment. Indeed, there are some clinical studies attempting to use peritoneal fluid to detect anastomotic leakages earlier than the clinical symptoms. Matthiessen et al. ${ }^{[16]}$ have collected intraperitoneal cytokines, IL-6, IL-10, and TNF-alfa through a pelvic drain from patients who underwent anterior resection for rectal cancer. They have concluded that through intraperitoneal monitoring of cytokines anastomotic leakage might be detected before clinical symptoms are manifested. A recent article by Fouda et al. ${ }^{[29]}$ checked the utility of intraperitoneal cytokine concentration and detection of bacteria in patients who underwent low anterior resection due to rectal cancer. Peritoneal samples were collected from the abdominal drains on the first, third, and fifth days postoperatively for peritoneal microbiological study and cytokine (IL-6, IL-I0, TNF) level measurement. They found that intraperitoneal bacterial colonization and cytokine levels were significantly higher in patients with anastomotic leakages, concluding that the technique could be used as an adjunct to the decision of the surgeon for colorectal anastomotic leakages. Therefore, early detection of bacteria in peritoneal samplings by PCR and culture in patients with colorectal anastomosis could be an alarming sign of anastomotic leak.

The present study indicated that with suboptimal anastomosis, although anastomotic leakage was very high, clinically significant anastomotic leak was rather infrequent. Early detection of anastomotic leakage was possible by running PCR on peritoneal samples as early as $\mathbf{7 2}$ hours. The clinical significance of the use of peritoneal washing samples from colorectal anastomosis remains to be determined.

\section{Acknowledgements}

This study was supported by a grant from Istanbul University Scientific Research Coordination Office with project number 474/27I 22005.

Conflict of interest: None declared.

\section{REFERENCES}

1. Kingham TP, Pachter HL. Colonic anastomotic leak: risk factors, diagnosis, and treatment. J Am Coll Surg 2009;208:269-78. CrossRef

2. Law WL, Choi HK, Lee YM, Ho JW, Seto CL. Anastomotic leakage is associated with poor long-term outcome in patients after curative colorectal resection for malignancy. J Gastrointest Surg 2007;11:8-15.

3. Lim M, Akhtar S, Sasapu K, Harris K, Burke D, Sagar P, et al. Clinical and subclinical leaks after low colorectal anastomosis: a clinical and radiologic study. Dis Colon Rectum 2006;49:1611-9. CrossRef

4. Rahbari NN, Weitz J, Hohenberger W, Heald RJ, Moran B, Ulrich A, et al. Definition and grading of anastomotic leakage following anterior resection of the rectum: a proposal by the International Study Group of Rectal Cancer. Surgery 2010;147:339-51. CrossRef
5. Peel AL, Taylor EW. Proposed definitions for the audit of postoperative infection: a discussion paper. Surgical Infection Study Group. Ann R Coll Surg Engl 1991;73:385-8.

6. Last M, Kurtz L, Stein TA, Wise L. Effect of PEEP on the rate of thoracic duct lymph flow and clearance of bacteria from the peritoneal cavity. Am J Surg 1983;145:126-30. CrossRef

7. Kane TD, Alexander JW, Johannigman JA. The detection of microbial DNA in the blood: a sensitive method for diagnosing bacteremia and/or bacterial translocation in surgical patients. Ann Surg 1998;227:1-9. CrossRef

8. Komen N, van der Wal HC, Ditzel M, Kleinrensink GJ, Jeekel H, Lange JF. Colorectal anastomotic leakage: a new experimental model.J Surg Res 2009;155:7-12. CrossRef

9. Ratanarat R, Cazzavillan S, Ricci Z, Rassu M, Segala C, de Cal M, et al. Usefulness of a molecular strategy for the detection of bacterial DNA in patients with severe sepsis undergoing continuous renal replacement therapy. Blood Purif 2007;25:106-11. CrossRef

10. Heininger A, Binder M, Schmidt S, Unertl K, Botzenhart K, Döring G. PCR and blood culture for detection of Escherichia coli bacteremia in rats. J Clin Microbiol 1999;37:2479-82.

11. Alves A, Panis Y, Pocard M, Regimbeau JM, Valleur P. Management of anastomotic leakage after nondiverted large bowel resection. J Am Coll Surg 1999;189:554-9. CrossRef

12. Bellows CF, Webber LS, Albo D, Awad S, Berger DH. Early predictors of anastomotic leaks after colectomy. Tech Coloproctol 2009;13:41-7. CrossRef

13. Doeksen A, Tanis PJ, Wüst AF, Vrouenraets BC, van Lanschot JJ, van Tets WF. Radiological evaluation of colorectal anastomoses. Int $\mathrm{J}$ Colorectal Dis 2008;23:863-8. CrossRef

14. Nicksa GA, Dring RV, Johnson KH, Sardella WV, Vignati PV, Cohen JL. Anastomotic leaks: what is the best diagnostic imaging study? Dis Colon Rectum 2007;50:197-203. CrossRef

15. Woeste G, Müller C, Bechstein WO, Wullstein C. Increased serum levels of $\mathrm{C}$-reactive protein precede anastomotic leakage in colorectal surgery. World J Surg 2010;34:140-6. CrossRef

16. Matthiessen P, Strand I, Jansson K, Törnquist C, Andersson M, Rutegård $\mathrm{J}$, et al. Is early detection of anastomotic leakage possible by intraperitoneal microdialysis and intraperitoneal cytokines after anterior resection of the rectum for cancer? Dis Colon Rectum 2007;50:1918-27. CrossRef

17. Skau T, Nyström PO, Ohman L, Stendahl O. The kinetics of peritoneal clearance of Escherichia coli and Bacteroides fragilis and participating defense mechanisms. Arch Surg 1986;121:1033-9. CrossRef

18. Dunn DL, Barke RA, Knight NB, Humphrey EW, Simmons RL. Role of resident macrophages, peripheral neutrophils, and translymphatic absorption in bacterial clearance from the peritoneal cavity. Infect Immun 1985;49:257-64.

19. Dumont AE, Maas WK, Iliescu H, Shin RD. Increased survival from peritonitis after blockade of transdiaphragmatic absorption of bacteria. Surg Gynecol Obstet 1986;162:248-52.

20. Küçükaydin M, Kocaoğlu C, Köksal F, Kontaş O. Detection of intestinal bacterial translocation in subclinical ischemia-reperfusion using the polymerase chain reaction technique. J Pediatr Surg 2000;35:41-3. CrossRef

21. Power DA, Cordiner SJ, Kieser JA, Tompkins GR, Horswell J. PCRbased detection of salivary bacteria as a marker of expirated blood. Sci Justice 2010;50:59-63. CrossRef

22. Bruns T, Sachse S, Straube E, Assefa S, Herrmann A, Hagel S, et al. Identification of bacterial DNA in neutrocytic and non-neutrocytic cirrhotic ascites by means of a multiplex polymerase chain reaction. Liver Int 2009;29:1206-14. CrossRef

23. Kobayashi H, Oethinger M, Tuohy MJ, Procop GW, Hall GS, Bauer TW. Limiting false-positive polymerase chain reaction results: detection 
of DNA and mRNA to differentiate viable from dead bacteria. Diagn Microbiol Infect Dis 2009;64:445-7. CrossRef

24. Song KM, Boatright KC, Drassler J, Strom MS, Nilsson WB, Bevan W, et al. The use of polymerase chain reaction for the detection and speciation of bacterial bone and joint infection in children. J Pediatr Orthop. 2009;29:182-8. CrossRef

25. Such J, Francés R, Muñoz C, Zapater P, Casellas JA, Cifuentes A, et al. Detection and identification of bacterial DNA in patients with cirrhosis and culture-negative, nonneutrocytic ascites. Hepatology 2002;36:13541. CrossRef

26. de Madaria E, Martínez J, Lozano B, Sempere L, Benlloch S, Such J, et al. Detection and identification of bacterial DNA in serum from patients with acute pancreatitis. Gut 2005;54:1293-7. CrossRef

27. Ono S, Tsujimoto H, Yamauchi A, Hiraki S, Takayama E, Mochizuki H. Detection of microbial DNA in the blood of surgical patients for diagnosing bacterial translocation. World J Surg 2005;29:535-9. CrossRef

28. Emet T, Bilsel Y, Tilki M, Sürmelioğlu A, User Y. Early diagnosis of colorectal anastomotic leakages by detection of bacterial genome. Ulus Travma Acil Cerrahi Derg 2005;11:195-200.

29. Fouda E, El Nakeeb A, Magdy A, Hammad EA, Othman G, Farid M. Early detection of anastomotic leakage after elective low anterior resection. J Gastrointest Surg 2011;15:137-44. CrossRef

\title{
DENEYSEL ÇALIŞMA - ÖZET
}

\section{Kolon rezeksiyonları sonrası suboptimal anastomoz: Deneysel çalışma \\ Dr. Mehmet Kamil Yıldız, ${ }^{1}$ Dr. İsmail Okan, ${ }^{2}$ Dr. Hasan Nazik, ${ }^{3}$ Dr. Gurhan Bas, ${ }^{4}$ Dr. Orhan Alimoglu, ${ }^{5}$ Dr. Mehmet İlktac, ${ }^{3}$ Dr. Emin Daldal, ${ }^{6}$ Dr. Mustafa Sahin, ${ }^{2}$ Dr. Nuray Kuvat, ${ }^{3}$ Dr. Betugul Ongen ${ }^{3}$}

\author{
${ }^{1}$ Haydarpaşa Numune Eğitim ve Araştırma Hastanesi, Genel Cerrahi Kliniği, İstanbul; \\ ${ }^{2}$ Gaziosmanpaşa Üniversitesi Tıp Fakültesi Genel Cerrahi Anabilim Dalı, Tokat; \\ ${ }^{3}$ İstanbul Üniversitesi İstanbul Tıp Fakültesi, Mikrobiyoloji ve Klinik Mikrobiyoloji Anabilim Dalı, İstanbul; \\ ${ }^{4}$ Ümraniye Eğitim ve Araştırma Hastanesi, Genel Cerrahi Kliniği, İstanbul; \\ ${ }^{5}$ Medeniyet Üniversitesi Göztepe Eğitim ve Araştırma Hastanesi, Genel Cerrahi Kliniği, İstanbul; \\ ${ }^{6}$ Vakıf Gureba Eğitim ve Araştırma Hastanesi, Genel Cerrahi Kliniği, İstanbul
}

AMAÇ: Suboptimal anastomozun nasıl sonuçlanacağı bilinmemektedir. Kolon rezeksiyonları sonrası anastomoz kaçağının erken tanısı hastanın doğru yönetiminde çok önemlidir.

GEREÇ VE YÖNTEM: Yirmi altı sıçan "kontrol”, "kaçak" ve "suboptimal anastomoz" adıyla üç gruba ayrıldı. Sırasıyla gruplara sham laparotomi, çekum ligasyonu-perforasyon ve kolon rezeksiyonu sonrası dört dikişle anastomoz yapıldı. Beşinci saatte, üçüncü ve dokuzuncu günlerde periferden kan örnekleri ve relaparotomi sonrası periton yıkama örnekleri alındı. Karnın içi makroskopik anastomoz kaçağı varlı̆ı için incelendi. Alınan yıkama örneklerinden aerobik ve anaerobik kültürlerle beraber I6 RNA ve E. Coli'ye özgü primerler kullanılarak polimeraz zincir reaksiyonu (PZR) yapıldı. BULGULAR: Değişik vücut sıvilarında 16 s RNA ve $E$. coli'ye özgün primerler kullanılarak yapılan PZR'nin sensitivitesi ve spesifisitesi sırasıyla \% I00 ve \%78 olarak bulundu. Üçüncü ve dokuzuncu günlerde alınan periton yıkama sıvılarında hem kültürde hem de PZR'de bakteri varlığı gösterildi. Karın içinin incelenmesinde 8 (\%80) sıçanda anastomoz kaçağı işaretleri gözlenirken, anastomozla ilişkili mortalite sadece 2 (\%20) sıçanda saptandı. TARTIŞMA: Kolon rezeksiyonu sonrası suboptimal anastomoza bağı anastomoz kaçağı oranı yüksektir ve 72 saat gibi erken bir sürede periton örneklerinden yapılan PZR ile tanı koymak olasıdır.

Anahtar sözcükler: Anastomoz kaçağı; erken tanı; kolorektal anastomoz; polimeraz zincir reaksiyonu; suboptimal anastomoz.

Ulus Travma Acil Cerrahi Derg 20 I4;20(6):40I-409 doi: 10.5505/tjtes.20।4.3।899 